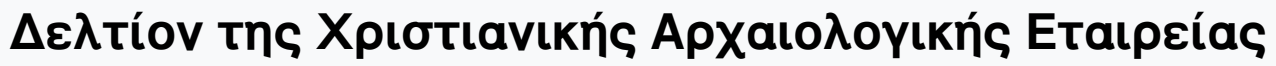

Tó 16 (1992)

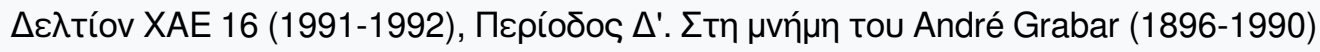

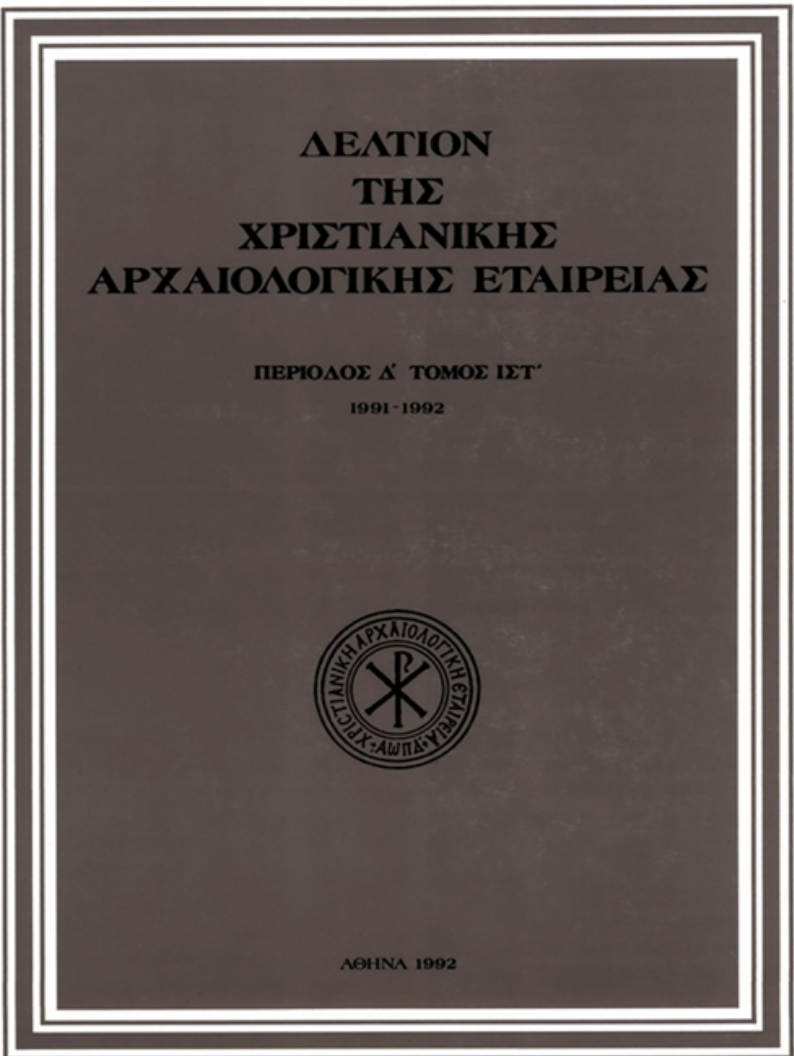

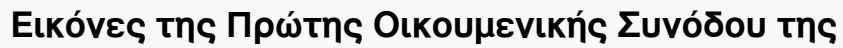
Níkalas

Christopher WALTER

doi: $\underline{10.12681 / \text { dchae. } 1068}$

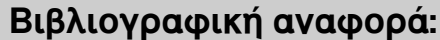

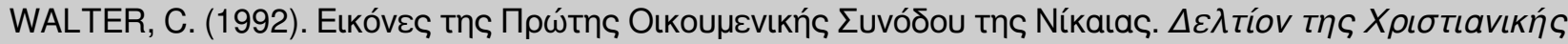

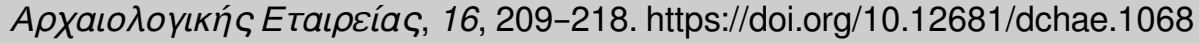




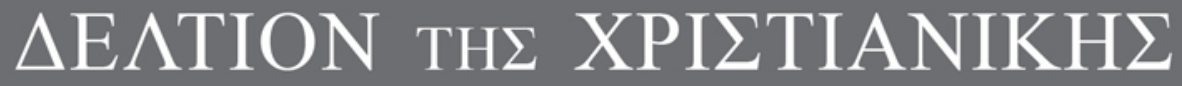 APXAIO $\Lambda$ OГIKH $\Sigma$ ETAIPEIA $\Sigma$}

\section{Icons of the First Council of Nicaea}

Christopher WALTER

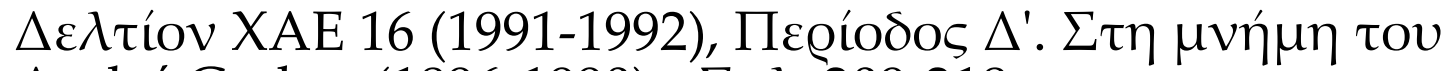
André Grabar (1896-1990)• $\sum \varepsilon \lambda .209-218$

A@HNA 1992 


\section{Christopher Walter}

\section{ICONS OF THE FIRST COUNCIL OF NICAEA}

In this volume of the $\Delta \varepsilon \lambda \tau$ tiov dedicated to the memory of the late André Grabar, it seems appropriate to return to the theme of my doctoral dissertation written under his direction ${ }^{1}$. When I published it, I knew only one icon of an oecumenical council, that which was painted by Damaskinos $^{2}$. Such icons are unknown in Byzantine art, and they are rare in post-Byzantine art, although less rare than I supposed. At least three others, besides that by Damaskinos, have been published ${ }^{3}$. There are also, no doubt, other unpublished ones besides those which have recently come to my notice and which are the main subject of this article ${ }^{4}$.

One of these icons of an oecumenical council, which I recently saw in a private collection, particularly merits publication by reason of the high quality of its execution and of its unusual iconography ${ }^{5}$ (Fig. 1). It measures $320 \mathrm{~mm}$ high by $233 \mathrm{~mm}$ wide by $24 \mathrm{~mm}$ thick. The wood on which it is painted is in excellent condition apart from a crack at the top, probably the result of holes being pierced in it at a later date, so that it could by suspended by string or wire. The icon is surrounded by a dark brown border, inside which the sunken area is entirely covered in gold. The upper part is slightly marred by craquelure, which has hardly affected the lower part, where colours have been layered on the gold. The subject of the icon, the first council of Nicaea, is inscribed in the legend at the top, written in red although the letters of the second line have been overpainted in black: [H] AГIA KAI OIKOYMENIKH A: $\Sigma Y N O \triangle O \Sigma$ / EN NIKAIA. At the top, above the legend, a segment has been painted in red lines, indicating that the fathers, represented below, are inspired by the Holy Spirit. There are six of them, three each side of the emperor. The faces are of a uniform brownish colour. The emperor has dark brown hair and a rounded beard. One bishop, no doubt Basil of Caesarea, has black hair ${ }^{6}$. The other five have dark hair rendered grey by the addition of abundant fine brush-strokes in white. Some of the bishops can be identified: the one with a conical head-dress is Spyridon ${ }^{7}$; the bald one is probably John Chrysostom $^{8}$; the one wearing a sakkos and crown is Alexander of Constantinople. The other two cannot be identified with certainty. The emperor's sakkos is similar to that of the bishop of Constantinople but longer, reaching to his feet. The loros is passed over his left arm, while in his right hand he holds the akakia. The vestments and crowns are ornamented in fine black lines with small dots of red. All the figures stand on a green ground which is separated from the gold border by a narrow black line. Two bishops hold the ends of an unrolled scroll, on which are inscribed the first phrases

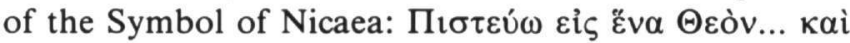

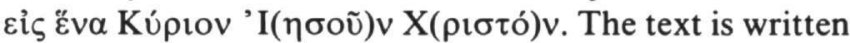
in black apart from some initial letters and the abbreviation marks above Jesus Christ which are in red.

Since the icon is not signed or dedicated, the only clues to its date and provenance are provided by the style and possibly by the iconography. So far as the style is concerned, it is not difficult to dissociate this icon from those which have recently been so well studied, the products of painters working in the Cretan tradition. It displays neither the delicate modelling nor the subtle and sophisticated use of colours characteristic of the Cretan School. Also absent are the exuberance and the developed exploitation of perspective to be found in seventeenth-century icons painted in the Cyclades and the Ionian Islands. One is therefore obliged to look north for comparative material, but, in doing so, one enters a region which, at present, is largely unchartered, and which stretches from the Adriatic coast across Macedonia into Thrace.

A general family likeness may be observed between this

1. Ch. Walter, L'iconographie des consiles dans la tradition byzantine, Paris 1970, cited hereinafter: Conciles. See also my articles Konzilien (written in 1977), RbK III, 1990, pp. 738-46; Le souvenir du II ${ }^{\mathrm{e}}$ concile de Nicée dans l'iconographie byzantine, Nicée II 787-1987, edited F. Boespflug and N. Lossky, Paris 1987, pp. 167-83.

2. Conciles, p. 91, fig. 46. See below, note 14.

3. See below, notes $22,24,50$.

4. I thank Ms Myrtali Potamianou for providing me with photographs of icons of councils in the Byzantine Museum, Athens, and authorising their publication, also Ms Maria Konstantoudaki and Ms Maria Vassilaki for valuable advice.

5. The owner, who wishes to remain anonymous, authorised my study of this icon which was originally in Constantinople.

6. Ch. Walter, Art and Ritual of the Byzantine Church, London 1982 , p. 108.

7. Ibid., 105; I d e m, The Portrait of Jakov of Serres in Londin. Additional 39626, Zograf 7 (1976), p. 67.

8. Walter, op.cit. (note 6), p. 106. 


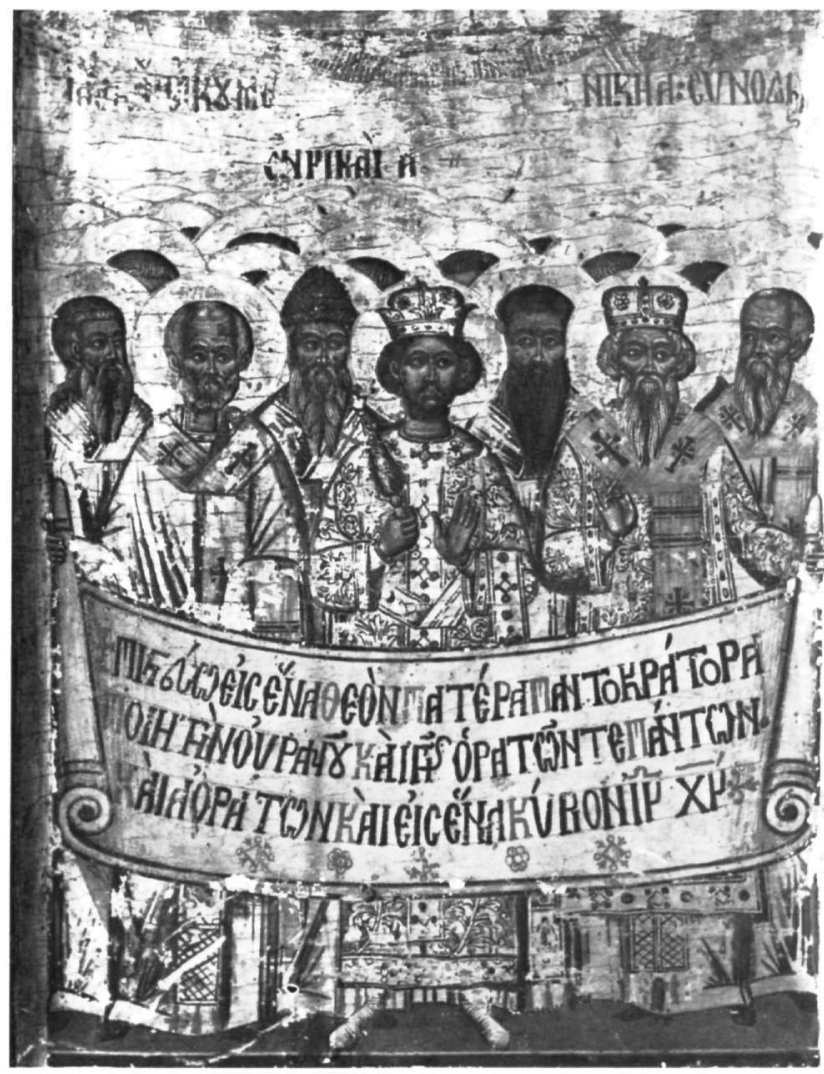

Fig. 1. First council of Nicaea (Private collection).

icon and the more academically styled icons produced in this vast region during the seventeenth century. They have in common their avoidance of plasticity, their fidelity to traditional iconographical details and their sobriety. However, specific elements of comparison are harder to formulate. A fairly close resemblance may be observed with the icon of Savvas in the Demetrios Ekonomopoulos collection ${ }^{9}$. They have in common the border, the gold background, the lower ground (which here is red not green) and the use of abundant fine brush-strokes in white on the beards. The pattern on Savvas's halo resembles that on the vestments in the council icon. Chrysanthi Baltoyanni suggested that the Savvas icon may have been executed on Lefkada. A more general resemblance may be observed with certain icons in the George Tsakyroglou collection - the Constantine and Helena, the archangel Michael, the Antipas and the Demetrius and Theodore, although Agapi Karakatsani does not venture a provenance for them ${ }^{10}$. Some traits in common may be noticed with the Peter and Paul in the Charocopos collection and the Nicolas in the Vallianos collection on Cephalonia ${ }^{11}$. However in no case would I be prepared to suggest that these icons were executed by the painter of the council icon. These comparisons only serve to situate him in one trend of later seventeenth-century icon painting.

Another possible provenance for this icon would be a workshop in Bulgaria, where religious culture in the seventeenth century was still predominantly Greek. Here also the state of research is not sufficiently advanced to permit more than a tentative comparison between the council icon and certain more sophisticated productions of the "School of Philippopolis" (Plovdiv). Notably an icon of Athanasius and Nicolas combines the same high level of meticulous detail with fidelity to tradition ${ }^{12}$. It is still in the church of Saint Petka the Older at Plovdiv. Two others of the same tradition, representing Marina and Stylianos, also from Plovdiv, are now in the Ecclesiastical Museum of History and Archaeology in Sofia ${ }^{13}$ (Fig. 2).

Before considering the iconography of this council icon, it will be as well to discuss briefly the other icons of the same subject. Outstanding among them, of course, is that by Michael Damaskinos ${ }^{14}$ (Fig. 3). In 1970 I had not yet seen it and knew it only from a rather inferior reproduction. Signed and dated 1591, it is the earliest known icon of a council. Large in size $(1.200 \mathrm{~mm} \times 910$ $\mathrm{mm} \times \pm 20 \mathrm{~mm}$ ), it forms part of a series of six icons painted by Damaskinos for the monastery of Saint An-

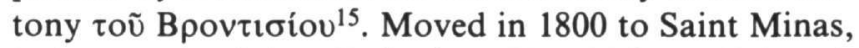
it is now in Saint Catherine, Herakleion. Although widely known and frequently cited, its iconography has not, so far as I am aware, been analysed in detail. The basic schema, with the emperor and church fathers seated in a semi-circle and the condemned heretic prostrate in the foreground, is conventional ${ }^{16}$. It was also customary to represent the Vision of Saint Peter of Alexandria in the background ${ }^{17}$. The bishops' features are individualised, although they do not all correspond to conventional portrait types. Spyridon, with his conical head-dress, may be identified, as can Sylvester of Rome, wearing a tiara with a sakkos. The bishop beside the emperor, also wearing a sakkos, would be Alexander of Constantinople. The bald bishop beside Sylvester would be John Chrysostom and the bishop with a black beard in the background beside Peter of Alexandria would be Basil. The fact that neither was present at the first council of Nicaea (any more than Sylvester of Rome and Peter of Alexandria) is irrelevant, for the icon is as much a celebration of orthodoxy as an official promulgation of dogma. Damaskinos underlines this subtly by introducing other details.

Prominent among these is the enthroned Gospel Book. In Byzantine art this occurs only once in the well-known miniature of the first council of Constantinople in the Paris Gregory of Nazianzus (Paris graec. 510, f. 355) ${ }^{18}$. 


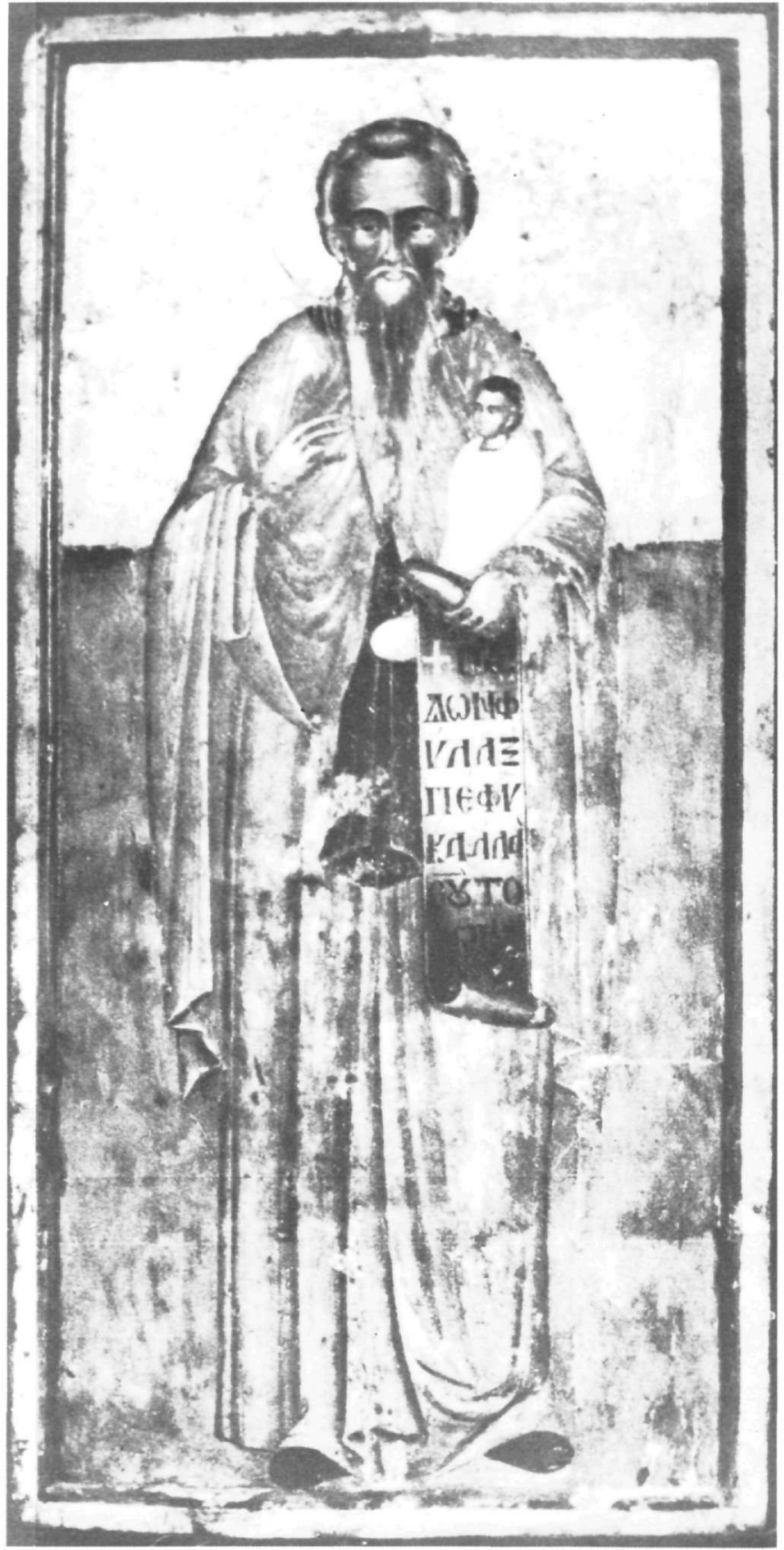

Fig. 2. Saint Stylianos (Ecclesiastical Museum, Sofia).

It is highly unlikely that Damaskinos knew this miniature, but he was obviously aware that, at the first councils, the Gospel Book was enthroned and presided in the place of Christ ${ }^{19}$. The text which he has inscribed on it: "I am the light of the world..." (John 8, 12) underlines this point. Below the enthroned Gospel Book Christ is represented conferring their mission on the apostles ${ }^{20}$. We are no doubt intended to infer that they transmit their mission to the fathers of the council.
Other original details are perhaps less significant: the Crucifixion on Sylvester's Gospel Book, following an established practice for their covers ${ }^{21}$; Christ Emmanuel on the altar cover doubling the infant Christ of Peter of Alexandria's vision; the single military guard, whose helmet, cuirass and shield, with the bicephalous eagle, do not obviously belong to Byzantine tradition in its purest form.

Besides the signature of Damaskinos in the bottom right hand corner and the text inscribed on the Gospel Book, there are two other legends. At the top the council is named: H AГIA K[AI] IEPA ПP $\Omega$ TH $\Sigma$ YNO $\Delta[\mathrm{O} \Sigma] \mathrm{H}$ EN NIKAIA. Arius holds an unrolled scroll on which is inscribed: APIO $\Sigma$ O $\Theta E O M A X O \Sigma \mathrm{K}[\mathrm{AI}]$ ПPOTO $\Sigma$ (sic) T $\Omega \mathrm{N}$ $\mathrm{KAI} \Omega N$. (Arius enemy of God and first of those who burn). Thus Damaskinos, in his personal style, uses traditional elements from Byzantine iconography to create a new and profound image of orthodox teaching on the first council of Nicaea.

Another published, but less well-known, icon of an oecumenical council is now in the National Museum, Belgrade $^{22}$. It measures $223 \mathrm{~mm} \times 320 \mathrm{~mm} \times 24 \mathrm{~mm}$. It is

9. Chrysanthi Baltoyanni, Icons. Demetrios Ekonomopoulos Collection, Athens 1986, no. 86, pp. 60-61, pl. 65. See also no. 118 , no. 128 , no. 172.

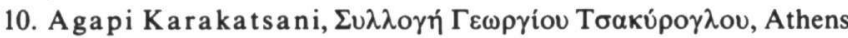
1980 , no. 30 , no. 49 , no. 50 , no. 88.

11. Cephalonia. Ecclesiastical Art, I, Region Kranaia, edited G.N. Moschopoulos, Argostoli 1989, no. 52, no. 70.

12. Petrana Toteva, Ikoni ot Plovdivski kraj, Sofia 1975, no page indicated.

13. V. Pandurski, Pametnici na izkustvoto v c'rkovnija istoriko-arheologičeski muzej Sofia, Sofia 1977, no. 175, no. 176, 395.

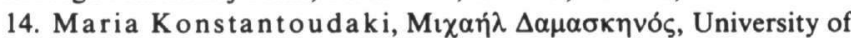
Athens 1988, II, pp. 290-291, III, figs. 90-95; M. Chatzidakis,

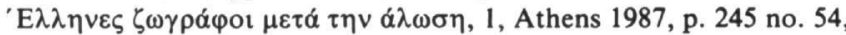
p. 251 fig. 7.

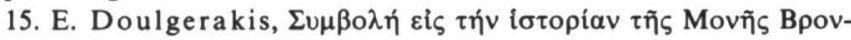

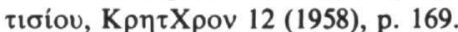

16. Conciles, pp. 233-235, 239-244.

17. Conciles, pp. 246-248; Walter, op.cit. (note 6), pp. 213-214.

18. Conciles, pp. 35-37, fig. 7; Leslie Brubaker, Politics, Patronage and Art in Ninth-Century Byzantium, DOP 39 (1985), pp. 4-6, fig. 4. 19. Conciles, pp. 147-148.

20. An analogous use of the Mission of the apostles to authentify the authority of the pope may be seen in the Triclinium of Leo III at the Lateran, Rome, $\mathrm{Ch}$. Walter, Papal Political Imagery in the Medieval Lateran Palace, CahArch 20 (1970), pp. 157-160, 174-175, fig. 2. For the iconography of the Mission of the apostles, see The Church of Haghia Sophia at Trebizond, edited D. Talbot-Rice, Edinburgh 1968 , pp. $172-77$

21. For example, the eleventh-century book cover in the Treasury of Saint Mark, Venice, D. Talbot-Rice, The Art of Byzantium, London 1959, no. 138, pp. 321-22.

22. Mirjana Ćorović-Ljubinković, Pećko-dečanska ikonopisa škola od XIV. do XIX. Veka, Belgrade 1955, no. XXIV; S. Radojčić, Ikona sa Balkana, Belgrade/Sofia 1966, no. 209, XCVII, CIV. 


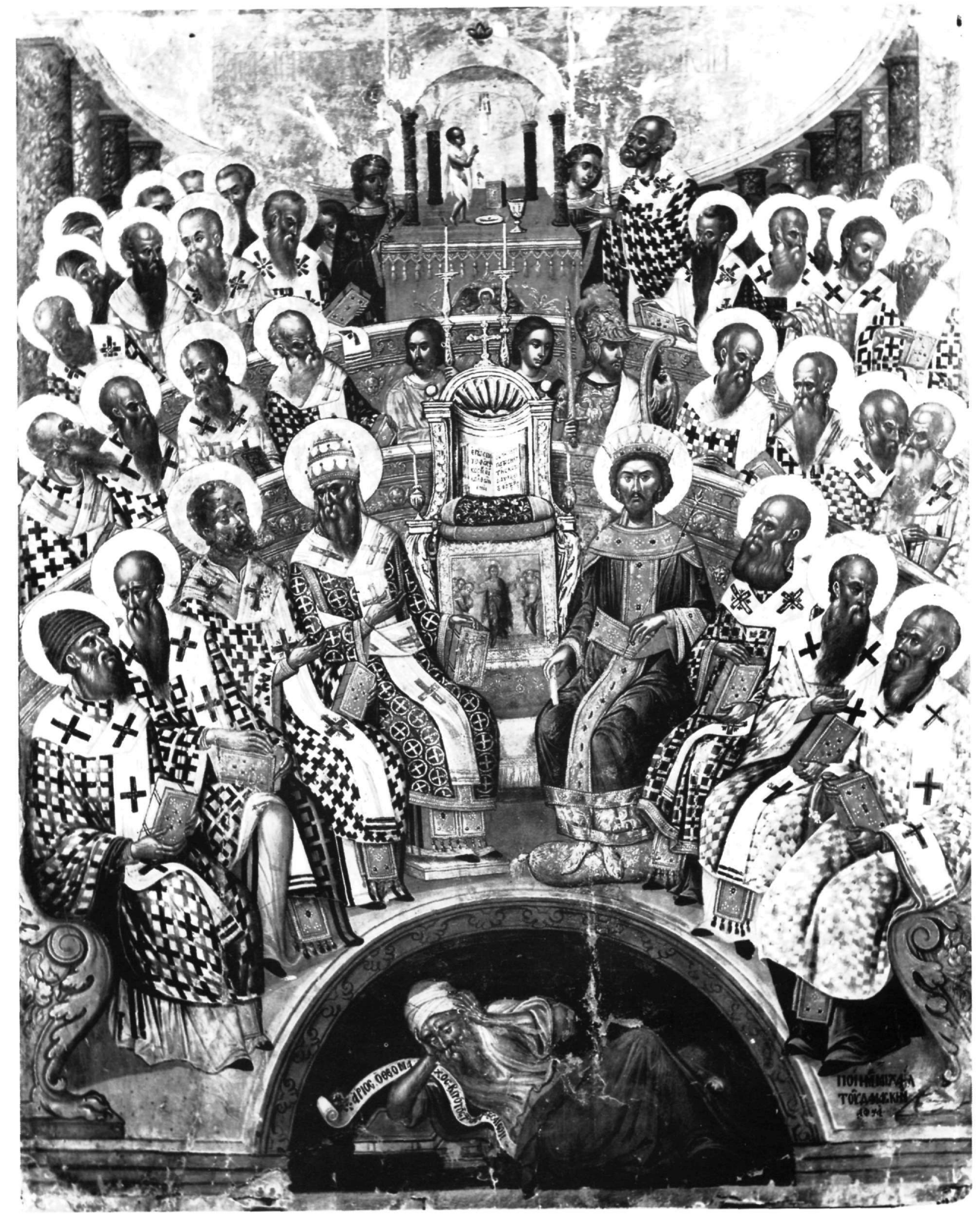

Fig. 3. First council of Nicaea (Damaskinos, St. Catherine, Herakleion). 
bilateral with portraits of Petka and Nedelja (Paraskevi and Kyriaki) on the other side. Again the iconography is conventional, although different from that of the Damaskinos icon. The emperor is enthroned between two bishops, seated in an exedra as if they were judging the dispute taking place below them. There, to the left, is a group of orthodox bishops with haloes. They confront the group of heterodox bishops, without haloes, to the right. The first of the orthodox bishops extends a Gospel Book toward the heretics, as if he was inviting them to accept true doctrine, but the front three of the heterodox raise their right hand to the side of their face, a gesture which probably signifies their deafness to truth. Mirjana Corović-Ljubinković attributes the icon to the School of Peć and Dečani, dating it to the second half of the seventeenth century and placing it in the tradition of the known painter Radul. This alternative formula for the representation of a council was already current in Serbia in the thirteenth century; it was used at Sopoćani (1263-1268) and Arilje (1296), as well as later at Dečani and Peć $^{23}$. However, since it was used for all the oecumenical councils, in the absence of a legend the council represented here cannot be identified.

A fourth icon, no. 3371 of the Ecclesiastical Museum of History and Archaeology, Sofia, measures $640 \mathrm{~mm} \times$ $450 \mathrm{~mm}$ (the thickness is not specified) ${ }^{24}$ (Fig. 4). At the top there is a legend: H AГIA K[AI] HKOYMENHKH (sic) $\mathrm{A}^{\prime} \Sigma \mathrm{INO} \Delta \mathrm{O} \Sigma($ sic) H $\Gamma E N O M E N H$ ПAPA TOY MEГA $\Lambda$ OY $\mathrm{K} \omega \nu \sigma \tau \alpha \nu \tau$ ivou. Basically the iconography is close to that of the Damaskinos icon, with the bishops seated in a semi-circle to either side of the emperor, while others, together with monks, stand behind the exedra accompanied by a single guard. Peter of Alexandria's vision is represented in the background, accompanied by the traditional phrases of his dialogue with the Christ Child: "Who has torn your clothing, Christ?" "The senseless Arius, Peter." (Not legible on the photograph) ${ }^{25}$. In the foreground Arius is prostrate at the feet of the fathers of the council. Božkov has proposed the identity of some of the bishops, but, except possibly for John Chrysostom, the bald bishop beside Sylvester, who wears a mitre, his identifications do not correspond to their known portrait types (Athanasius, Basil, Gregory of Nyssa). On the other hand, Spyridon, with his conical head-dress, whom Božkov did not identify, appears to the extreme right of the front row behind the exedra. On the other side of the icon there is a portrait of Nicolas. Pandurski plausibly proposes a seventeenth-century date, but gives no information as to the icon's provenance.

Two further icons in the Byzantine Museum, Athens, both hitherto unpublished, also seem dateable to the

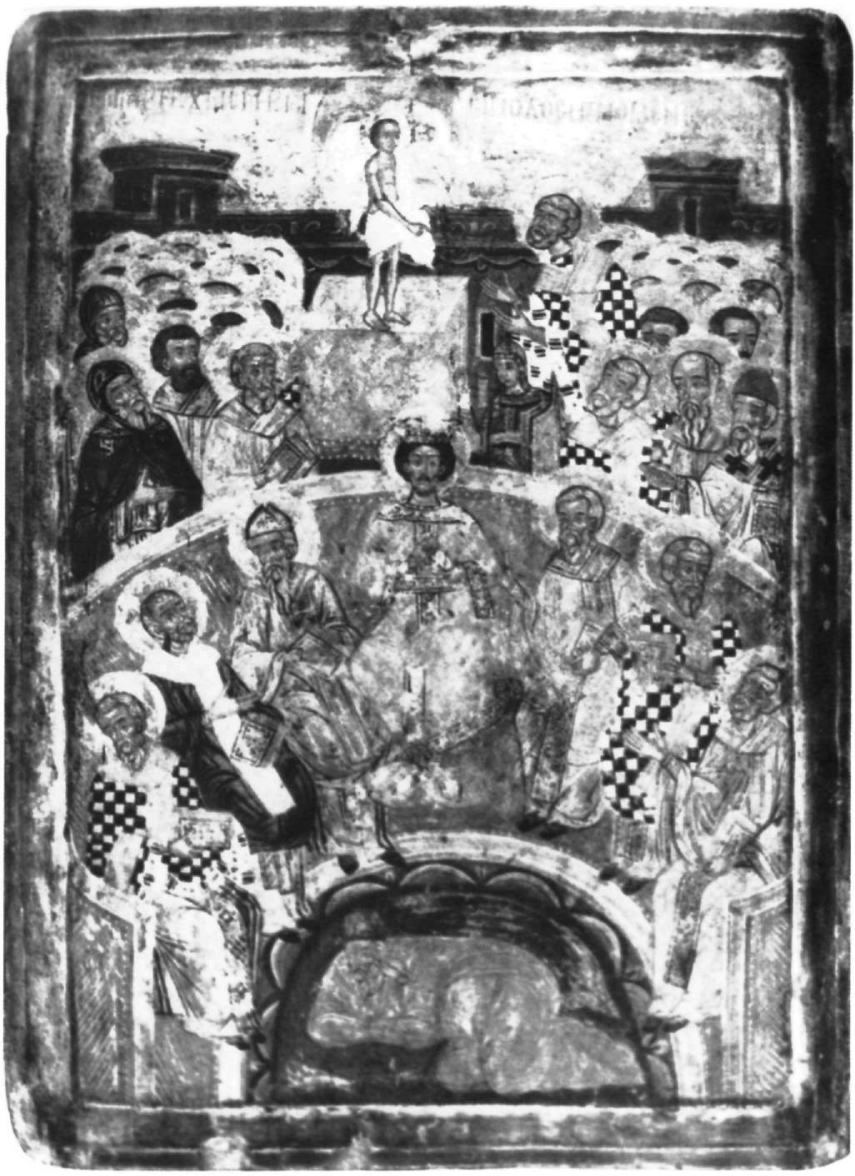

Fig. 4. First council of Nicaea (Ecclesiastical Museum, Sofia).

seventeenth century. No. 1726 measures $330 \mathrm{~mm} \times 250$ mm (Fig. 5). The bishops, of whom, curiously, none are haloed, sit in a semi-circle to left and right of the emperor. Further figures, including at least two guards, stand behind the exedra. There is no legend, but the bishop to the right who leans forward wears a head-dress like Spyridon. This detail, together with the prostrate heretic in the foreground, makes it likely that this is the first council of Nicaea. The ornate background, with arches and a cupola, recalls the Pentecost at San Georgio dei Greci, Venice, which M. Chatzidakis has attributed to the School of Tzanes ${ }^{26}$. However, the gestures of the figures are more exuberant and dramatic, although lacking the

23. Conciles, pp. 107, 109, 111-113, 115, 116, 257-58. For the dates of the paintings at Sopoćani and Arilje, see V. Djurić, Vizantijske freske u Jugoslaviji, Belgrade 1974, pp. 41, 44.

24. Pandurski, op.cit. (note 13), p. 395, fig. 171-73; A. Božkov, B'lgarskata ikona, Sofia 1986, pp. 18-19, fig. 9-10.

25. Conciles, p. 246.

26. M. Chatzidakis, Icônes de Saint-Georges des Grecs et de la Collection de l'Institut Hellénique, Venice 1962, no. 136, p. 152, pl. 66. 


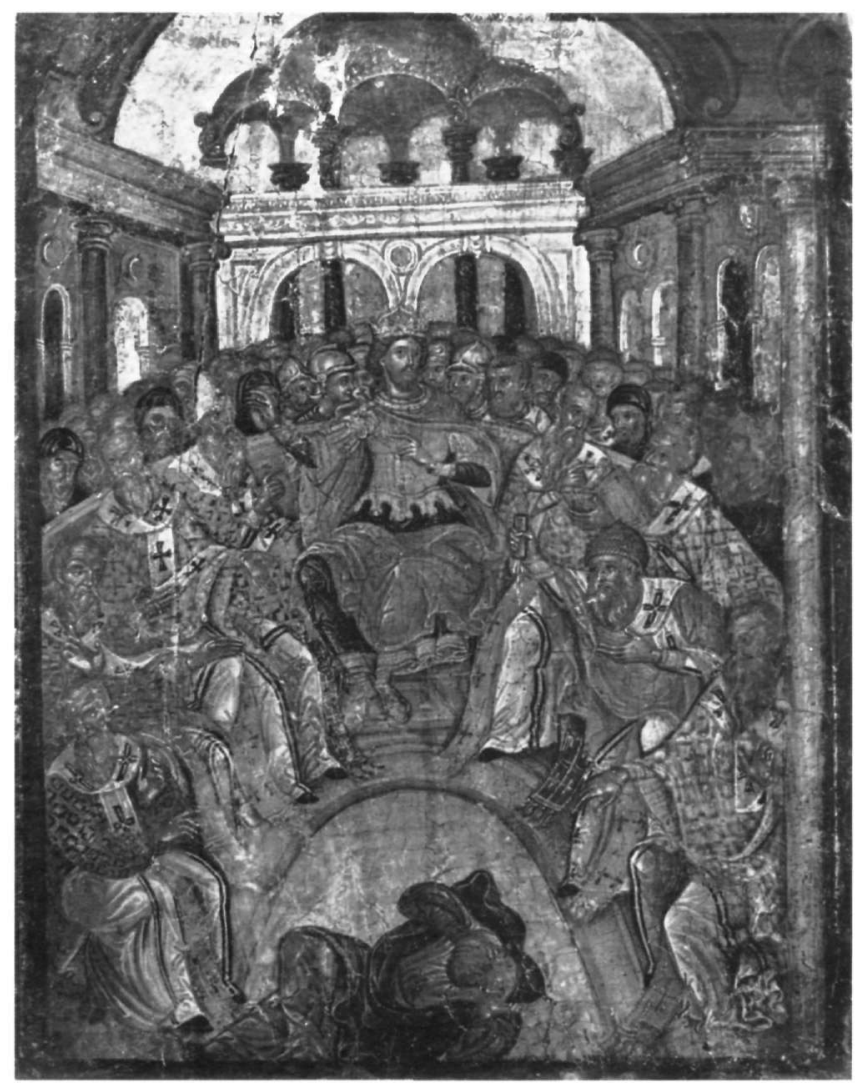

Fig. 5. Oecumenical council (Byzantine Museum, Athens, no. 1726).

delicacy and finesse of the better seventeenth-century painters like Damaskinos. Perhaps this icon can be attributed to a lesser artist working either in Venice or in the Ionian Islands.

No. 114 of the Byzantine Museum, formerly in the church of the Trinity, Thessaloniki, measures $355 \mathrm{~mm} \times$ $265 \mathrm{~mm}$ (Fig. 6). Again the bishops are grouped around the emperor in a semi-circle. The bishop to the right of the emperor (Sylvester?) wears the sakkos and a pointed head-dress with a chequered pattern. Behind the exedra stand other bishops and a single guard. In the background the Vision of Peter of Alexandria is represented and in the foreground Arius prostrate. Although there is no legend, the presence of Peter of Alexandria makes it clear that this is the first council of Nicaea. The sobriety of the style suggests that it also belongs to the "Northern School". If it was originally painted for the church of the Trinity, it may well be due to a local artist.

With the exception of the icon in the National Museum, Belgrade, which repeats another iconographical type well-attested in monumental painting, all these latter icons use the same formula, of which the earliest surviving examples are in the Paris Gregory ${ }^{27}$ and the Meno-

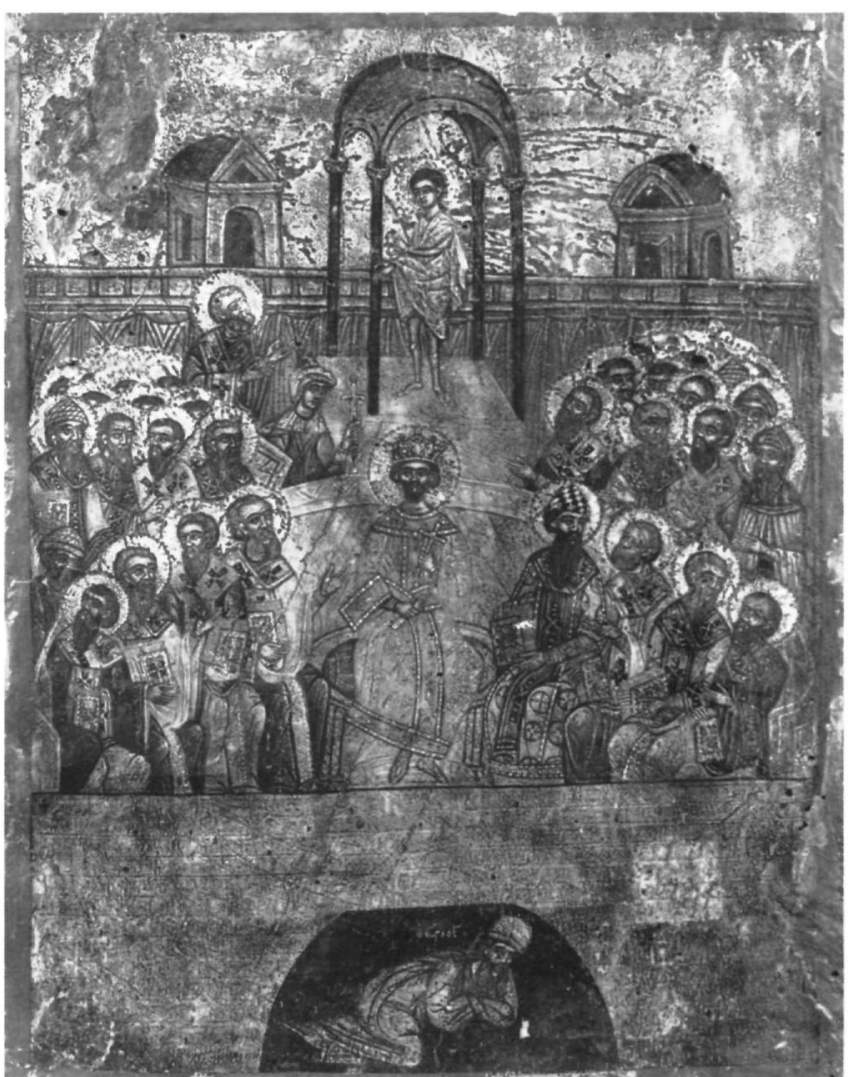

Fig. 6. First council of Nicaea (Byzantine Museum, Athens, no. 114).

logium of Basil II, Vatican graec. 1613, p. 108 ${ }^{28}$ : the emperor and bishops sit in judgment on and condemn the heretic. In three cases the Vision of Peter of Alexandria is associated with the council, a practice first attested in the metropolitan church at Mistra ${ }^{29}$ (first quarter of the fourteenth century? $)^{30}$ and later widespread. But even no. 1726 of the Byzantine Museum, from which the Vision of Peter of Alexandria is absent, is also a representation of the first council of Nicaea.

However, the unpublished icon in a private collection with which this article begins is not unique. There is one closely similar to it in the monastery of Koutloumous, Mount Athos, measuring $340 \mathrm{~mm} \times 260 \mathrm{~mm} \times 35 \mathrm{~mm}$. Parts of the border are damaged but the painting itself is intact $^{31}$ (Fig. 7). Two bishops stand each side of the emperor, while the top of the head and halo of others are visible behind them. The bishop to the extreme left wears the kind of head-dress associated with Cyril of Alexandria. Possibly the bishop on the right of the emperor is Nicolas. Stylistically there are traits common to the two icons, the fine brush-strokes in white on three of the bishops' beards and the pattern on the emperor's sakkos. However, the execution is less competent. The 


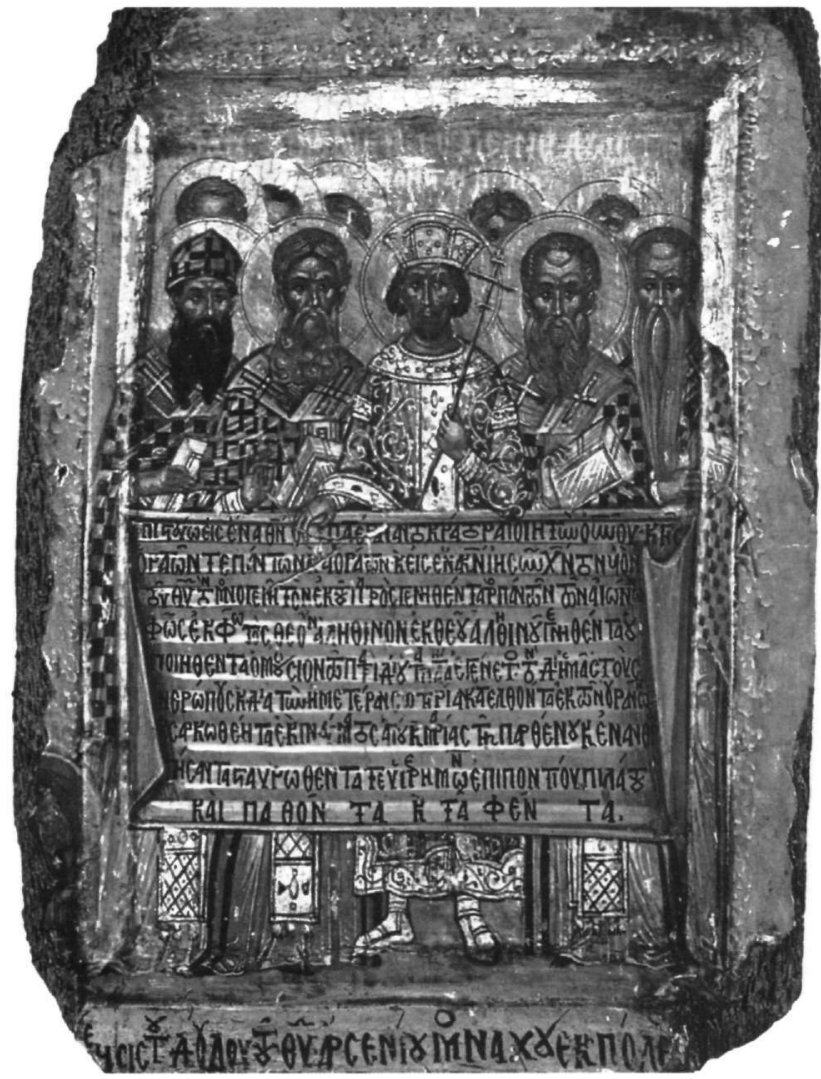

Fig. 7. First council of Nicaea (Monastery of Koutloumous).

figures, bunched together, extend to left and right outside the space reserved for the subject, and the large scroll, on which is inscribed the Symbol as far as kai $\pi \alpha \theta$ óv $\tau \alpha \kappa[\alpha i] \tau \alpha \varphi \varepsilon \dot{v} \tau \alpha$, seems to float in the air. Of the legend at the top in red, the first line is hardly legible ( $\dot{\varepsilon} v$ Nikaía?). It then continues: H АГIA HKOYMENIKH ПPOTH $\Sigma I N O \triangle O \Sigma$ TOY ME(ГA) $\Lambda O Y$ K $\Omega N \Sigma T A N T I N O Y$. At the bottom there is a votive legend: $[\Delta] E H \Sigma I \Sigma$ TOY $\triangle O Y A O Y$ TOY $\Theta(E O) Y$ APSENIOY MONAXOY EK ПO$\Lambda \mathrm{E}[\Omega \Sigma]$. It is unlikely that the monk Arsenius could be identified, but he may have brought the icon with him from Constantinople.

There is another icon of the first oecumenical council in the refectory of the monastery of Iviron, Mount Athos (Fig. 8). It measures $220 \mathrm{~mm} \times 210 \mathrm{~mm} \times 20 \mathrm{~mm}$. On this icon the standing figures are grouped under an arch. The first phrases of the Symbol are inscribed on the unrolled roll before them. There is a legend: H ПРОТI $\Sigma Y N O \triangle O \Sigma$ EN NIKAIA. A third icon of an oecumenical council, about which I have no exact information, is in the monastery of Stavronikita.

The Damaskinos icon and no. 3371 in Sofia are large in format. Most of the others are about the same size (ca

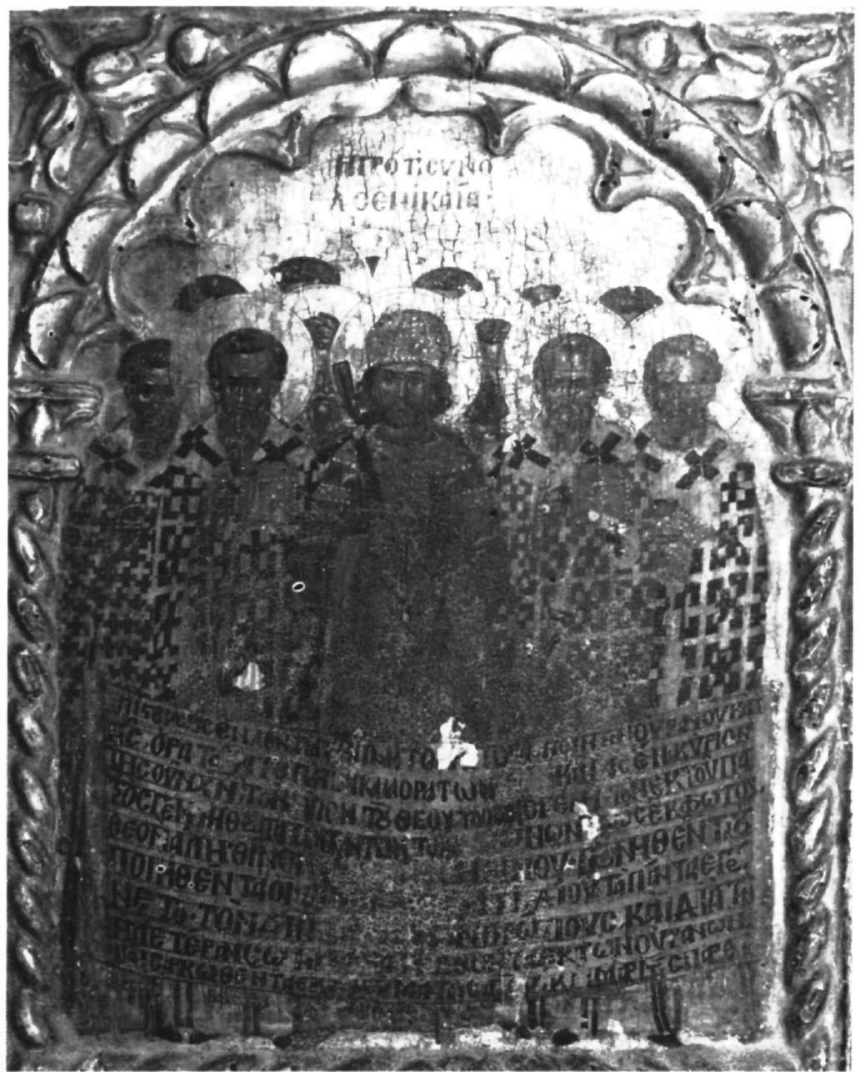

Fig. 8. First council of Nicaea (Monastery of Iviron).

$350 \mathrm{~mm} \times 250 \mathrm{~mm}$ ). This suggests a certain standardisation of format, if not of iconography, which would have been convenient for a proskynesis icon, to be exposed for veneration on the day when the first council of $\mathrm{Ni}$ caea was commemorated. The choice of date for this commemoration is a somewhat complex subject ${ }^{32}$. It seems that originally the Byzantines commemorated the first council of Nicaea on May 29th. Later the commemoration took place on the Sunday between the Ascension and Pentecost. Although primarily the feast of the first council of Nicaea, it came to englobe all the oecumenical councils. This explains why only one proskynesis icon of a council was necessary. Usually named in the accompanying legend the first council of Nicaea, it nevertheless englobed, like the commemoration, all

27. See above, note 18 .

28. Conciles, pp. 37-38.

29. Conciles, pp. 89-90.

30. M. Chatzidakis, Mistra, Athens 1985, p. 43.

31. I gratefully thank Mr Charalambos Dendrinos for providing me with information about the three Athonite icons.

32. S. Salaville, La fête du concile de Nicée et les fêtes de conciles dans le rit byzantin, EO 24 (1925), pp. 445-470. 


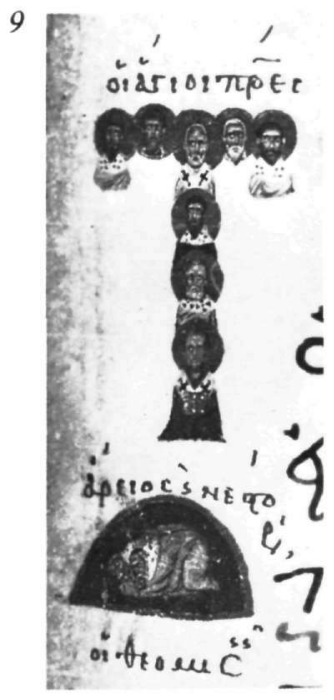

the others. The name of the commemoration in calendars came to be simply $\tau \tilde{\omega} v \Pi \alpha \tau \varepsilon \rho \omega v^{33}$.

This liturgical title helps to explain why the alternative iconographical type persisted, representing not, strictly speaking, a council but "the Fathers". There are antecedents in Byzantine art. The initial $\mathrm{T}$ of the reading for the commemoration of the first council of Nicaea in the Lectionary New York, Morgan 639, f. 42, is made up of the busts of a motley collection of bishops ${ }^{34}$ (Fig. 9). It is accompanied by the legend: oi $\alpha \gamma_{10} \pi[\alpha \tau \dot{\varepsilon}] \rho \varepsilon \varsigma$. Closer in iconography, except that the emperor is absent, is the miniature illustrating the commemoration of the sixth oecumenical council (September 16th) in another Lectionary, Vatican graec. 1156, f. $253^{35}$ (Fig. $10)$. Equally close is the miniature for the commemoration of the Holy Fathers (Sunday before Christmas) in the Lectionary Dionysiou 587, f. 126. Here, as on the icons, a number of Fathers in the back row are indicated by the top of their head and their halo ${ }^{36}$ (Fig. 11). These three miniatures all appear in a liturgical manuscript. Their iconography would have been inappropriate in the more usual pictures of councils, wall-paintings which served as an official promulgation of orthodox doctrine. However, this objection could not be made in the case of a proskynesis icon for a commemoration motivated by the Church's desire to glorify God by the

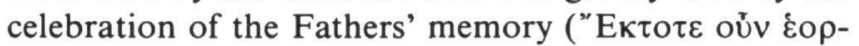

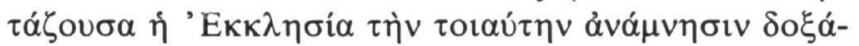
$\zeta \varepsilon$

A final detail in this alternative iconography calling for comment is the unrolled roll inscribed with the opening words of the Symbol of Nicaea. Although legends are often present on monumental representations of councils, the practice of inscribing them on a roll is rare. In

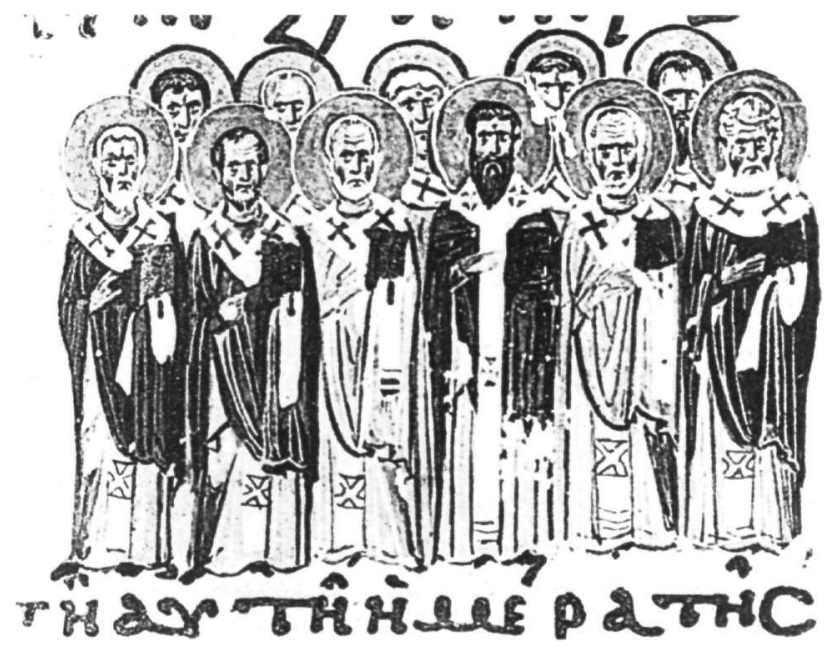

10

fact the only examples known to me are those in the series of oecumenical councils in the church of the Nativity, Arbanasi, Bulgaria, painted between 1632 and $1649^{38}$. The iconography of all these pictures is that of an official promulgation, but in three of them (the first council of Nicaea, the first council of Constantinople and the second council of Nicaea), the participants hold an unrolled roll inscribed with a legend (Fig. 12).

This fact might lend a little support to my tentative suggestion that the icon described at the beginning of this article was painted in a Greek atelier operating in Bulgaria in the seventeenth century. However against this it may be argued that this group of icons with a similar iconography were painted on Mount Athos or possibly brought there from an atelier in Constantinople. Unfortunately our present knowledge of icon-painting in the northern sphere of Greek religious culture is too slight to admit of certitude where exact dates and provenances are concerned. On the other hand it can be affirmed that in the seventeenth century it became fashionable to paint proskynesis icons of councils, which rarely betray signs of Cretan or Venetian influence. On some the iconographical formulae used in monumental painting were taken up. On others a more specifically liturgical formula was used. Deriving from that which was current in Byzantine liturgical manuscripts for representing the Fathers of the Church, it nevertheless introduces original elements. The emperor figures among the Fathers and the first phrases of the Symbol of Nicaea are inscribed on a large extended scroll.

\section{APPENDIX}

In my two articles cited above (note 1), I added to the repertory in my original study of the iconography of 


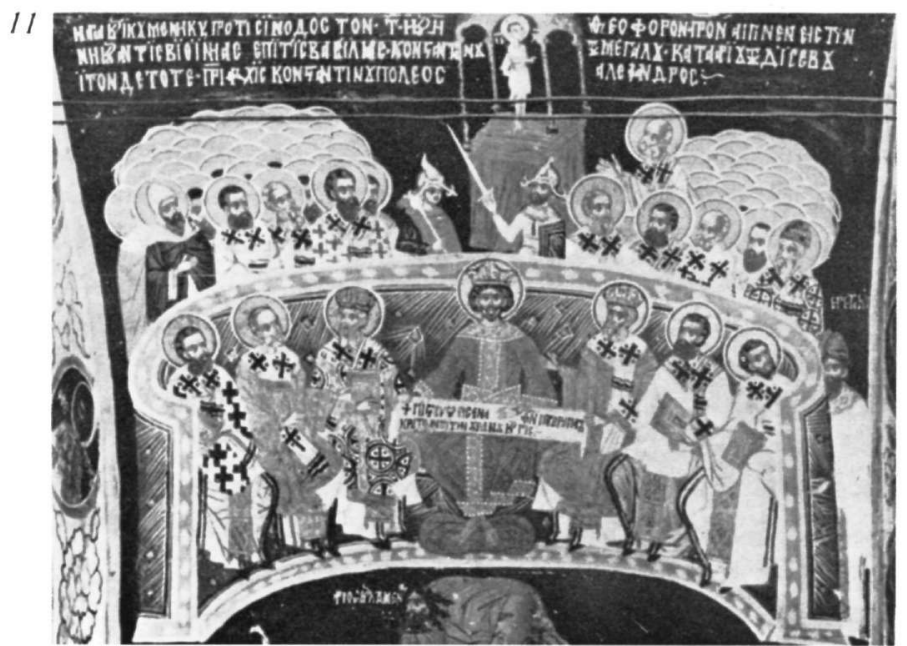

councils further examples not known to me when I wrote it. Besides the icons described in the main body of this article, I add here a few additional examples which I had not noted previously.

1. The fragmentary scenes of councils in the narthex of the catholicon of the Vlacherna monastery near Arta (early fourteenth century?) ${ }^{39}$.

2. Fragment of an icon, Byzantine Museum, Athens, no. 1497, from Asia Minor, measuring $525 \mathrm{~mm} \times 265 \mathrm{~mm}$. From a photograph it is difficult to distinguish the details precisely, some of which seem unusual: the members of the Trinity in a mandorla in the central background (?); Christ and the Virgin restoring his omophorion and Gospel Book to Nicolas in the right background $(?)^{40}$.

3. Biographical icon of Spyridon with a scene of the first

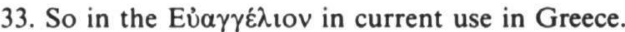

34. K. Weitzmann, The Constantinopolitan Lectionary Morgan 639, Studies in Art and Literature for Belle da Costa Greene, edited Dorothy Miner, Princeton 1954, p. 372; Conciles, pp. 38-39, fig. 8. 35. Conciles, p. 40 , fig. 9.

36. Ch. Walter, The Date and Content of the Dionysiou Lectionary,

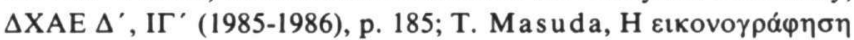

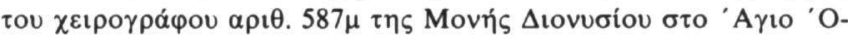

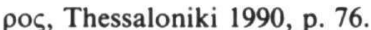

37 . Commemoration of the fifth oecumenical council, July 25 th, Synaxarium CP, edited H. Delehaye, Brussels 1902, 843, lines 1-3. Cited by Salaville, art.cit. (note 31), p. 470.

38. Conciles, pp. 83-87, fig. 38, 39, 44.

39. Myrtali Acheimastou-Potamianou, The Byzantine WallPaintings of Vlacherna Monastery (Area of Arta), Actes du XVe Congrès International d'études byzantines, II 1, Art et archéologie, Communications, Athens 1981, pp. 3-4, fig. 10.

40. Unpublished.

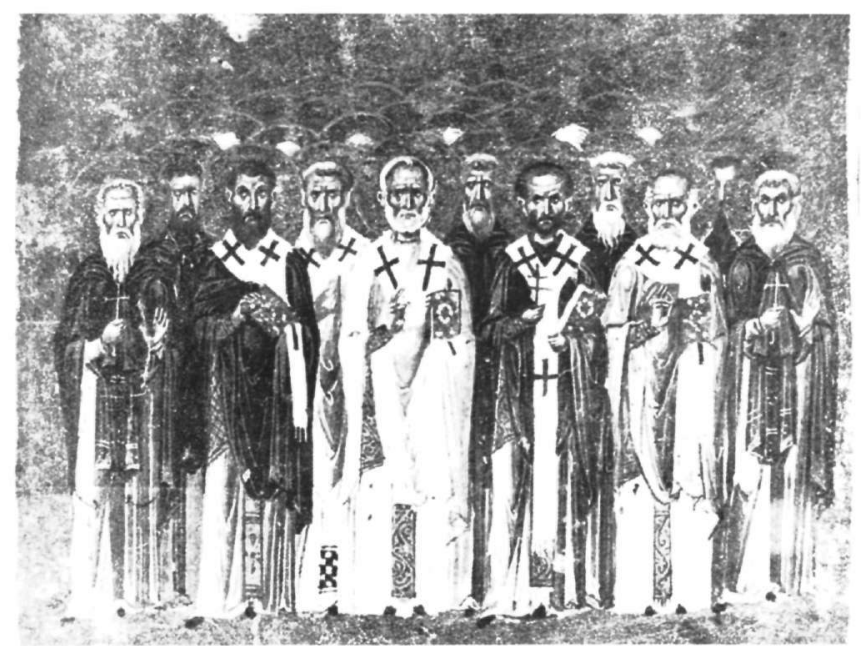

Fig. 9. The holy Fathers (Morgan Lectionary, f. 42, New York).

Fig. 10. Sixth oecumenical council (Lectionary, Vatican graec. 1156, f. 253).

Fig. 11. The holy Fathers (Lectionary Dionysiou 587, f. 126). Fig. 12. First council of Nicaea (Arbanasi).

Fig. 13. First council of Nicaea (Byzantine Museum, Athens, no. 707$)$.

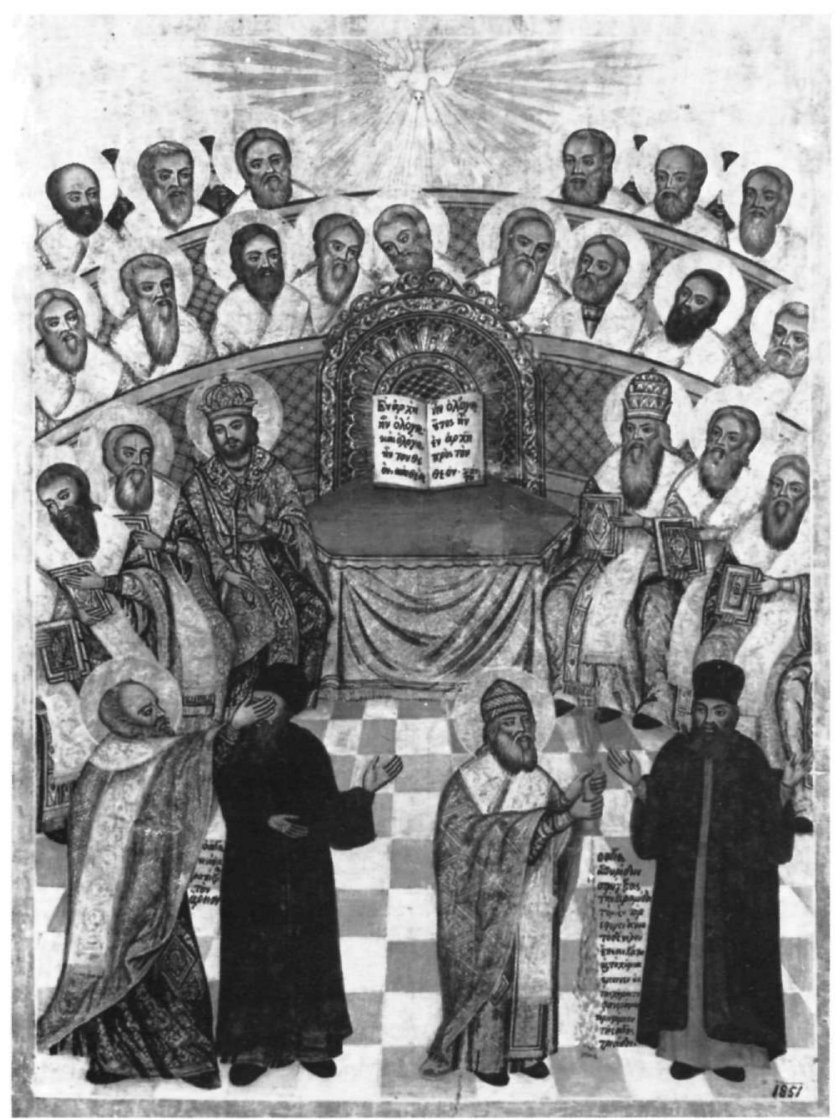


council of Nicaea by Emmanuel Tzanes, dated 1636, Museo Correr, Venice ${ }^{41}$.

4. Biographical icon of Nicolas with a scene of Nicolas slapping Arius at the first council of Nicaea, dated 1780, church of Saint Nicolas, Svoronata, Cephalonia ${ }^{42}$.

5. Wall-painting of the second oecumenical council by Mitrofan Zograf, dated 1817, church of Saint George, monastery of Zographou, Mount Athos ${ }^{43}$.

6. Icon of the second council of Nicaea, dated 1829 and measuring $340 \mathrm{~mm} \times 300 \mathrm{~mm}$, church of the archangel Michael, Trjavna ${ }^{44}$.

7. Icon of the first council of Nicaea, Byzantine Museum, Athens, no. 707, from the Panagouda, Thessaloni$\mathrm{ki}$, dated 1851 and measuring $405 \mathrm{~mm} \times 280 \mathrm{~mm}$ (Fig. 13). This icon merits special attention, because, although the artist has not followed exactly the prescription of Dionysios of Fourna for the representation of the first council of Nicaea, he has introduced one detail which I have not seen elsewhere. Spyridon stands to the right beside a philosopher, amazed by his act of squeezing a brick from which fire rises and water falls. Thus far Dionysios's text ${ }^{45}$. However, the legend on the icon is

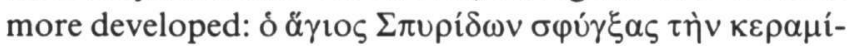

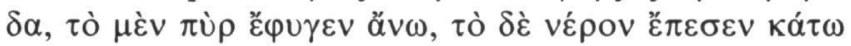

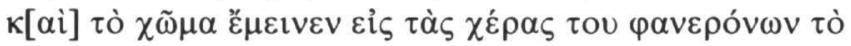

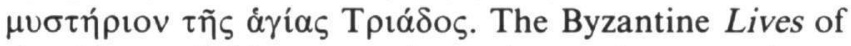
Spyridon call him a wonderworker and recount how, although a simple peasant, he refuted a philosopher at the first council of Nicaea ${ }^{46}$. However, they do not recount this prodigy, nor have I found it recounted elsewhere ${ }^{47}$. Nevertheless Didron interprets it in his edition of the Hermeneia in the same way as the legend on the icon as manifesting the mystery of the Trinity ${ }^{48}$. The dove hovering in the background is another detail prescribed by Dionysios of Fourna but not generally represented in pictures of councils. The other detail of Nicolas slapping Arius is fairly common in post-Byzantine paintings of the first council of Nicaea; it is recounted in some versions of his Life $^{49}$.

8. Icon of the second council of Nicaea attributed to George Klontzas, late sixteenth century, State Museum of Art, Copenhagen ${ }^{50}$.

9. Series of frescoes of the seven oecumenical councils in the narthex of the church of the Archangels, Kučevište, near Skopje ${ }^{51}$. Unpublished. On the south wall, there are four councils, developed with the orthodox confronting heretics below the emperor and bishops. The three pictures on the north wall are less developed. They were most probably painted in 1631 .

10. Series of frescoes of oecumenical councils in the narthex of the church of the Dormition, Elešnički monastery, near Sofia ${ }^{52}$. They are damaged, and only the first, second and sixth councils survive on the east wall. They are accompanied by inscription in Slavonic, without which it would be difficult to identify these scenes as councils, because their iconography is exceptional. For example, not a single bishop is represented. Pandurski dated them to the seventeenth century. Pending their full publication, I would suggest that they reflect the opposition of Bulgarian monks to the Greek hierarchy, and imply that authority in the Church was not transmitted by bishops. The "Fathers" are dressed as monks and haloed.

11. The first council of Nicaea is represented on the west wall of the narthex of the church of the Nativity of the Virgin in the monastery of Rožen near Melnik ${ }^{53}$. The paintings date from 1732. The council is represented in the conventional way, with Arius prostrate before the emperor and bishops seated in an exedra and Saint Peter of Alexandria behind the exedra facing the Christ Child on the altar. The picture forms part of a calendar series, corresponding to the Sunday between the Ascension and Pentecost. To the left and right of it, these two feasts are illustrated by the appropriate scenes.

12. This article was already in the press when I came across the icon in the Benaki Museum which is very similar to that reproduced in Fig. $1^{54}$.

41. G. Mariacher, Il Museo Correr di Venezia, Venice 1957, pp. 239, 241; Chatzidakis, op.cit. (note 26), pp. 95, 128.

42. Op.cit. (note 11), no. 315 .

43. A. Božkov and A. Basiliev, Hudožestvenoto nasledstvo na manastira Zograf, Sofia 1981, pp. 107-108, fig. 79.

44. Božkov, op.cit. (note 24), pp. 21, 39, fig. 12.

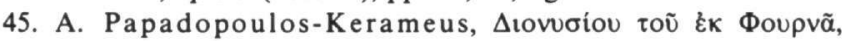

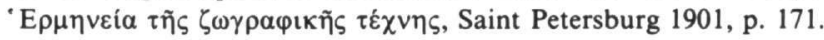

46. Walter, op.cit. (note 6), p. 99.

47. P. Van Den Ven, La légende de S. Spyridon évêque de Trimithonte, Louvain 1953, pp. $140^{*}-141^{*}$, notes the existence of unpublished popular Lives of Spyridon.

48. M. Didron, Manuel d'iconographie chrétienne, Paris 1845, p. 348 note 1 .

49. Walter, op.cit. (note 6), p. 104.

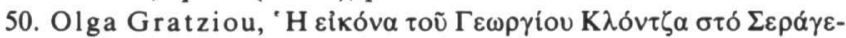

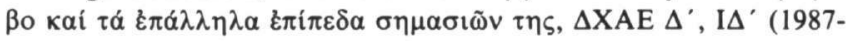
1988), pp. 25-28, fig. 6 For earlier bibliography, see p. 25 note 58.

51. S. Petković, Zidno slikartstvo na području pećke patrijarsije 1557-1614, Novi Sad 1965, pp. 94-95; G. Subotić, Iz epigrafske gradje postvizantiskog doba, Saopštenje 20-21 (1988-1989), p. 88. I thank Ms Aneta Serafimova for introducing me to this church.

52. V. Pandurski, Elešniškijat manastir, Sofia 1981, pp. 13, 15, 70, figs. 34, 35, 38, 40. I thank Ms Elka Bakalova and Mr Georgije Gerov for introducing me to this and the following church.

53. Elka Bakalova, Roženskijat manastir, Sofia 1990, p. 13, reproduced in part, p. 46.

54. A. Xyngopoulos, 'H $\Sigma \cup \lambda \lambda \circ \gamma \eta \dot{~ ' E \lambda \varepsilon ́ v \eta ऽ ~} \Sigma \tau \alpha \theta \alpha \dot{\tau} \tau o u$, Athens 1951, no. 22 , pp. $26-27$, fig. 20 . 